\title{
Development of analytical methods for mycotoxins, and research for food safety
}

\author{
Setsuko TABATA \\ Tokyo Metropolitan Institute of Public Health \\ 3-24-1, Hyakunin-cho, Shinjuku-ku, Tokyo 169-0073, Japan \\ TEL: 03-3363-3231 (EX. 6430), \\ FAX: 03-3363-3215, 03-3368-4060 \\ E-mail : Setsuko_Tabata@member.metro.tokyo.jp
}

\begin{abstract}
Summary
The major mycotoxins such as aflatoxins, patulin, ochratoxins, citrinin and fumonisins, zearalenone were researched for food safety. Analytical methods for aflatoxins, patulin, ochratoxins, citrinin and fumonisins were developed. Each method consists of quantification and confirmation, and has good performance in recovery, sensitivity, repeatability, and selectivity. With these methods, mycotoxin contamination in food and foodstuffs were studied. Aflatoxins were found in nuts, cereals, spices, beans and dairy products. Some samples contained more than $10 \mu \mathrm{g} / \mathrm{kg}$ of aflatoxin $\mathrm{B}_{1}$, the regulatory level then in Japan. Aflatoxin contamination in buckwheat, coix seed, crude sugar, white pepper and red pepper were found at the first time in Japan. Physical, chemical and biological degradation of aflatoxins was investigated. Pure aflatoxins were reduced by some physical or chemical procedure. But detoxification of aflatoxins in foods was quite difficult because of the stability of aflatoxins in foods. Patulin was found in some apple juice. It was the first finding of patulin contamination in Japan. Patulin was also found in domestic apples. This fact revealed that patulin contamination occurs in Japan. Ochratoxins were found in cereals, coffee, cacao, and fruit products. Most levels of ochratoxins were less than $1 \mu \mathrm{g} / \mathrm{kg}$. Citrinin was found in cereals, and some of them were co-contaminated with ochratoxin. Developing analytical methods, examinations, and regulations for mycotoxins are considered to be important for food safety.
\end{abstract}

Key words : aflatoxin, patulin, ochratoxin, citrinin, fumonisin, analytical method, contamination, detoxification

(Received : July 4, 2012)

\section{Introduction}

In 1980s, when I started the research on mycotoxins, the situation of mycotoxins in Japan was quite different from that in now. Regulation was set on only aflatoxin $\mathrm{B}_{1}$, and the official method for aflatoxin was not applicable to many kinds of food samples. I have been analyzing mycotoxins in foods, developing analytical methods. In this paper, my research on mycotoxins for food safety will be described.

\section{Aflatoxins}

Analytical method An analytical method for quantification and confirmation of aflatoxins was developed $^{1)}$ (Scheme 1). This method is applicable to most kind of foods, such as nut, cereal, spice, been, and 
dairy product. The selectivity, trueness, repeatability of this method is conformed to the Japanese method validation guideline.

After addition of $3-10 \mathrm{~mL}$ of water, aflatoxins were extracted with $100 \mathrm{~mL}$ of chloroform from $20 \mathrm{~g}$ of ground sample by shaking $15 \mathrm{~min} .50 \mathrm{~mL}$ of extract solvent was collected, completely dehydrated with sodium sulfate, and applied to florisil ( $0.7 \mathrm{~g}$ )

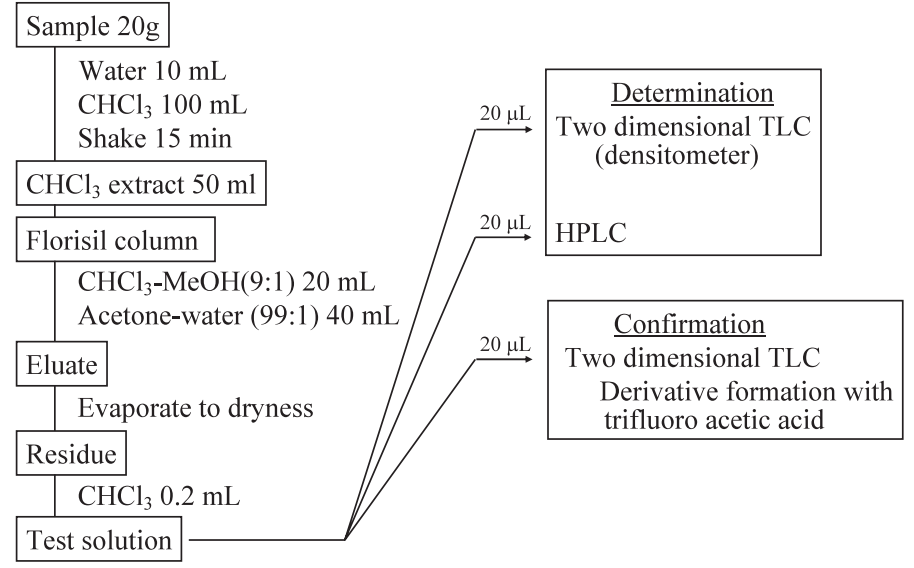

Scheme 1. Analytical method for aflatoxins column chromatography. After loading, the florisil column was washed with $3 \mathrm{~mL}$ of chloroform and $20 \mathrm{~mL}$ of chloroform-methanol (9:1) solution. Then aflatoxins were eluted with $40 \mathrm{~mL}$ of acetone-water (99:1) solution. The eluate was evaporated to dryness, and dissolved with chloroform. The test solution contains $10 \mathrm{~g}$ of purified sample.

Then aflatoxins were determined and confirmed by high-performance liquid chromatography with fluorescence detection (HPLC-FL) and/or two-dimensional high performance thin layer chromatography (HPTLC) using densitometer with Xenon-lamp. Recoveries of aflatoxins were $91 \%$ for $\mathrm{B}_{1}, 89 \%$ for $\mathrm{B}_{2}, 78 \%$ for $G_{1}, 78 \%$ for $G_{2}$, and $92 \%$ for $M_{1}$. Limits of quantification and confirmation were $0.1 \mu \mathrm{g} / \mathrm{kg}$ for each aflatoxin.

Contamination A total of 7,500 samples, consisting of nuts, cereals, spices, beans, and dairy products, collected from commercial markets and from the food industry in Tokyo during the period of 1982 to 1996, were examined ${ }^{2-5}$. As shown on Table 1 and 2, aflatoxins were found in nuts (peanut, pistachio nut, sesame seed, etc.), cereals (coix seed, corn, buckwheat, etc.), crude sugar, beans (beans for bean-jam), spices (nutmeg, paprika, red pepper, white pepper, etc.), and dairy product (natural cheese). The highest incidence of aflatoxin contamination was found in nutmeg $(60 \%)$, and highest level of aflatoxin $\mathrm{B}_{1}$ was found in pistachio nut $(1,382 \mu \mathrm{g} / \mathrm{kg})$. To protect consumer from the harmful effects of aflatoxins, regulatory limits had been set on aflatoxin $B_{1}$ (total aflatoxins at present) in all foods at the level of $10 \mu \mathrm{g} / \mathrm{kg}$ in Japan. More than $10 \mu \mathrm{g} / \mathrm{kg}$ of aflatoxin $\mathrm{B}_{1}$ were sometimes found in imported nuts, cereals, beans and spices. These foods were eliminated by administrative disposition. These data were reported to the Ministry of Health and Welfare and the Ministry put out inspection order.

The incidence and level of aflatoxins in peanut samples were listed on Table 3. Of 391 samples of whole peanut examined, only one contained aflatoxins. The positive sample was a raw material, not a product sold in the market. On the other hand, the incidences were high in peanut paste and crushed or powdered peanut. This was probably due to two reasons. One was deference in grade of peanut; commercial whole peanuts were of higher grade, and crushed peanuts, whose grade the consumer cannot estimate, were of lower grade. The other reason was difference in sampling size; the amount of peanut crushed for powder or paste was much more than $1 \mathrm{~kg}$, our sampling scale for analysis. As aflatoxin contamination is very partial, the more the 
Table 1. Incidence and level of aflatoxins

\begin{tabular}{|c|c|c|c|c|c|c|c|}
\hline \multirow{2}{*}{ Sample } & \multirow{2}{*}{$\begin{array}{l}\text { No. of } \\
\text { sample }\end{array}$} & \multirow{2}{*}{$\begin{array}{c}\text { No. of } \\
\text { positive }\end{array}$} & \multirow{2}{*}{$\begin{array}{c}\text { No. of } \\
\text { violation }^{* 1}\end{array}$} & \multicolumn{4}{|c|}{ Aflatoxin found $(\mu \mathrm{g} / \mathrm{kg})$} \\
\hline & & & & $\mathrm{B}_{1}$ & $\mathrm{~B}_{2}$ & $\mathrm{G}_{1}$ & $\mathrm{G}_{2}$ \\
\hline \multicolumn{8}{|l|}{ Nut } \\
\hline Peanut & 459 & 35 & 3 & $0.4-21.7$ & $0.1-5.3$ & $0.3-22.1$ & $0.1-6.8$ \\
\hline Pistachio nut & 481 & 9 & 7 & $0.8-1382$ & $0.1-260$ & 306 & 48.3 \\
\hline Cashew nut & 212 & 0 & & & & & \\
\hline Almond & 151 & 0 & & & & & \\
\hline Brazil nut & 8 & 1 & 1 & 10.2 & 0.8 & 3.2 & 0.3 \\
\hline Walnut & 71 & 0 & & & & & \\
\hline Macadamia nut & 20 & 0 & & & & & \\
\hline Pine seed & 17 & 0 & & & & & \\
\hline Pumpkin seed & 23 & 0 & & & & & \\
\hline Mixed nut & 17 & 0 & & & & & \\
\hline Sesame seed & 47 & 5 & & $0.6-2.4$ & $0.2-0.5$ & ND & ND \\
\hline Others & 101 & 0 & & & & & \\
\hline \multicolumn{8}{|l|}{ Cereals } \\
\hline Rice & 170 & 1 & & 0.5 & ND & ND & ND \\
\hline Wheat & 352 & 0 & & & & & \\
\hline Barley & 276 & 0 & & & & & \\
\hline Oat & 39 & 0 & & & & & \\
\hline Rye & 21 & 0 & & & & & \\
\hline Coix seed & 212 & 48 & 1 & $0.1-14.9$ & $0.1-1.8$ & $0.3-0.7$ & ND \\
\hline Corn & 474 & 4 & & $0.1-0.4$ & ND & ND & ND \\
\hline Buckwheat & 252 & 23 & & $0.1-8.8$ & $0.1-0.9$ & $0.2-0.8$ & 0.1 \\
\hline Mixed flour & 81 & 0 & & & & & \\
\hline Sugar & 31 & 12 & & $1.0-1.5$ & $0.1-0.2$ & ND & ND \\
\hline Others & 78 & 1 & & 0.4 & ND & ND & ND \\
\hline \multicolumn{8}{|l|}{ Beans } \\
\hline Soy bean & 113 & 0 & & & & & \\
\hline Beans for bean-jam & 916 & 14 & 4 & $0.1-254$ & $0.4-8.5$ & ND & ND \\
\hline Coffee bean & 77 & 0 & & & & & \\
\hline Others & 100 & 0 & & & & & \\
\hline \multicolumn{8}{|l|}{ Spices } \\
\hline Black pepper & 120 & 0 & & & & & \\
\hline White pepper & 220 & 21 & & $0.1-2.3$ & $0.1-0.3$ & ND & ND \\
\hline Red pepper & 81 & 31 & 3 & $0.2-27.7$ & $0.1-1.2$ & $0.1-2.1$ & $0.1-0.2$ \\
\hline Paprika & 44 & 26 & & $0.2-6.5$ & $0.1-0.3$ & ND & ND \\
\hline Nutmeg & 257 & 155 & 17 & $0.2-60.3$ & $0.1-6.5$ & $0.1-15.8$ & $0.1-0.4$ \\
\hline Mace & 56 & 0 & & & & & \\
\hline Caraway & 21 & 0 & & & & & \\
\hline Thyme & 25 & 0 & & & & & \\
\hline Cinnamon & 18 & 0 & & & & & \\
\hline Coriander & 13 & 0 & & & & & \\
\hline Laurel & 23 & 0 & & & & & \\
\hline Clove & 18 & 0 & & & & & \\
\hline Нор & 52 & 0 & & & & & \\
\hline Ginger & 22 & 0 & & & & & \\
\hline Sage & 27 & 0 & & & & & \\
\hline Mixed spice & 161 & 28 & & $0.2-1.9$ & ND & ND & ND \\
\hline Others & 128 & 0 & & & & & \\
\hline
\end{tabular}

*1: detected more than $10 \mu \mathrm{g} / \mathrm{kg}$ of $\mathrm{AFB}_{1} \quad \mathrm{ND}:<0.1 \mu \mathrm{g} / \mathrm{kg}$ 
Table 2. Aflatoxin contamination in dairy products (1982-1996)

\begin{tabular}{lccccccc}
\hline \multirow{2}{*}{ Sample } & No. of Sample & No. of positive & \multicolumn{5}{c}{ Aflatoxin found $(\mu \mathrm{g} / \mathrm{kg})$} \\
\cline { 3 - 7 } & & & $\mathrm{B}_{1}$ & $\mathrm{~B}_{2}$ & $\mathrm{G}_{1}$ & $\mathrm{G}_{2}$ & $\mathrm{M}_{1}$ \\
\hline Natural cheese & 354 & 44 & ND & ND & ND & ND & $0.1-1.2$ \\
Processed cheese & 23 & 0 & & & & & \\
Others & 8 & 0 & & & & & \\
Total & 385 & 44 & & & & & \\
\hline
\end{tabular}

$\mathrm{ND}:<0.1 \mu \mathrm{g} / \mathrm{kg}$

Table 3. Incidence and level of aflatoxins in peanut and peanut products

\begin{tabular}{lcccc}
\hline \multirow{2}{*}{ Sample } & No. of samples & No. of positives & \multicolumn{2}{c}{ Level of $\mathrm{AFB}_{1}(\mu \mathrm{g} / \mathrm{kg})$} \\
\cline { 4 - 5 } & & & Av. & Range \\
\hline Whole & 391 & $1(1)$ & 10.9 & 10.9 \\
Crushed & 7 & $2(1)$ & 7.3 & $0.7-13.9$ \\
Powdered & 17 & $11(1)$ & 5.5 & $0.2-21.7$ \\
Paste & 34 & 16 & 1.2 & $0.1-2.7$ \\
Oil & 11 & 5 & 0.6 & $0.5-0.7$ \\
Total & 459 & 35 & & \\
\hline ( $)$ : No. over regulatory limit $(10 \mu \mathrm{g} / \mathrm{kg})$ &
\end{tabular}

sampling size, the more the probability of including aflatoxin-contaminated grain.

Changes in contamination of aflatoxins Comparing by year, the aflatoxin contamination in foods was inconstant (Fig. 1). In 1982, 34\% of natural cheese was contaminated with aflatoxin $\mathrm{M}_{1}$, then the incidence decreased year by year, and no aflatoxin has been detected since 1985 . Aflatoxin $\mathrm{M}_{1}$ in dairy product is a metabolite of aflatoxin $\mathrm{B}_{1}$ in dairy cattle. Therefore, these results indicated that aflatoxin contamination in feed for dairy cattle decreased after 1985. The reason for this seems to be that the number of countries with legislation controlling aflatoxin in feedstuffs increased from 22 in 1981 to 35 in 1986 . Also, the European Community directive was tightened in 1984, when the tolerance for aflatoxin $\mathrm{B}_{1}$ in feedstuffs for dairy cattle was reduced from 20 to $10 \mu \mathrm{g} / \mathrm{kg}$.

Aflatoxin contamination in buckwheat was found in 1982-1985. The highest incidence was $46 \%$, found in 1985. After 1985, no aflatoxin was detected. The reason for the change in buckwheat might be that buckwheat from Brazil was not imported 1985-1996.

A high incidence was found in nutmeg throughout the period, reaching over 80\% during 1985-1990. The levels were also high; some lots were discarded by executive order. Some trading company checked aflatoxin before import, and conducted the farmers to prevent aflatoxin contamination. After then, contamination level and incidence were reduced.

These facts indicated that the causes of the change in mycotoxin contamination in commercial foods in Japan consist of two factors. One was factor in the country of origin; weather and regulation for mycotoxins in the country. And the other was factor in Japan; Examination of mycotoxins at port of entry for imported foods, choice of county of origin, and education about mycotoxins to farmers. 


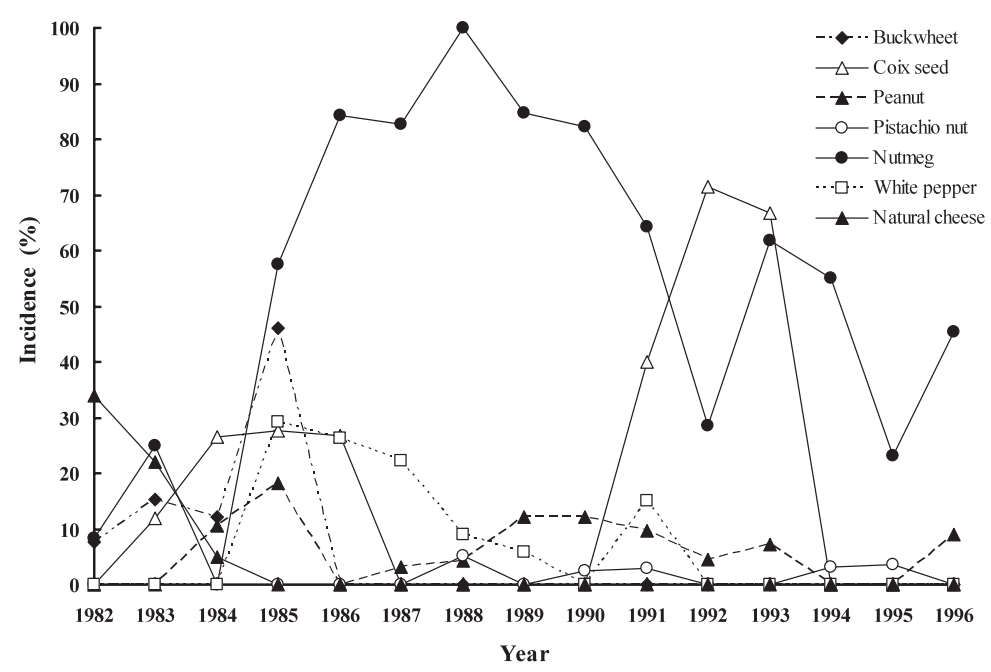

Fig. 1. Change in the incidence of aflatoxins

Fate in cooking process The fate of 4 kinds of aflatoxins, aflatoxin $\mathrm{B}_{1}, \mathrm{~B}_{2}, \mathrm{G}_{1}$ and $\mathrm{G}_{2}$, during cooking process, especially boiling, was studied ${ }^{6)}$. The samples, in which aflatoxin contamination was found in our survey, were cooked to evaluate the behavior of aflatoxins during cooking process so that we could better estimate the real intake of aflatoxins from those aflatoxin-contaminated foods. Using corn, buckwheat, coix seed, nutmeg, and white pepper naturally or artificially contaminated with aflatoxins, we cooked porridge from the corn and ciox seed, and the nutmeg and white pepper as seasoning in sautéing and making soup.

Sixty percent or more of aflatoxins remained after any one of the cooking process, and there was no significant difference among the four aflatoxins in rate of loss. In other words, the aflatoxins could not be effectively degraded or eliminated in either sautéing or boiling process.

Biological conversion ${ }^{7)} \quad$ The conversion of aflatoxin $\mathrm{B}_{1}$ by six kinds of fungi, previously reported to assimilate aflatoxin $\mathrm{B}_{1}{ }^{8)}$, was investigated. After incubation at $25{ }^{\circ} \mathrm{C}$ for 4 weeks, 5 kinds of fungi reduced aflatoxin $\mathrm{B}_{1}$. Among them, only Humicola fuscoatra showed a marked difference in the aflatoxin conversion rate between intact and sterilized mycelia. The intact mycelia of the fungus reduced aflatoxin $\mathrm{B}_{1}$ level to one tenth of the starting level, but the sterilized mycelia had no effect on aflatoxin $\mathrm{B}_{1}$. Aflatoxin $\mathrm{B}_{1}$ was converted in the mycelia but not in the broth filtrate. These finding indicated that the conversion by Humicola fuscoatra was a biological reaction. The conversion products of aflatoxin $B_{1}$ by the fungus were identified to be aflatoxicol A and B by TLC and HPLC, and all the reduced aflatoxin $\mathrm{B}_{1}$ was converted to aflatoxicols. The toxicity of aflatoxicol is near to aflatoxin $\mathrm{B}_{1}$. Therefore, the conversion by this fungus was seemed not being effective for detoxification of aflatoxin $\mathrm{B}_{1}$.

Degradation by food additives Degradation of four aflatoxins (aflatoxin $B_{1}, B_{2}, G_{1}$ and $G_{2}$ ) by food additives was studied ${ }^{9}$. By acidic food additives, aflatoxin $B_{1}$ and $G_{1}$ were converted to aflatoxin $B_{2 a}$ and $G_{2 a}$, respectively. After treatment with alkaline food additives, lactone rings of aflatoxins were opened and aflatoxins were converted to water-soluble compounds. Since this reaction is reversible, the compounds re-formed to aflatoxins in acidic condition. Some food additives reduced pure aflatoxins. But most of them 
were not effective for reducing aflatoxins in corn. Of aflatoxins added to corn, $80 \%$ aflatoxin $\mathrm{B}_{1}$ reduced after treatment with the solution of sodium hydrogen sulfite $\left(\mathrm{NaHSO}_{3}\right)$.

Conversion by sodium hydrogen sulfite The conversion product of aflatoxin $\mathrm{B}_{1}$ by the treatment with sodium hydrogen sulfite, in the condition similar to the process of making cornstarch was investigated ${ }^{10}$. We treated pure aflatoxin $\mathrm{B}_{1}$ with sodium hydrogen sulfite in the similar condition used in making cornstarch, found the conversion product, and identified its chemical structure. Sulfur group was added to the double bond in bis-fran ring of aflatoxin $\mathrm{B}_{1}$. And then we applied the treatment to artificially and naturally aflatoxincontaminated corn, and confirmed that the treatment actually produce the compound from aflatoxin $\mathrm{B}_{1}$ in corn. This fact indicated that the compound is actually produced in the process of making cornstarch.

The toxicity of $\mathrm{AFB}_{1}$ is manifested by the activation by cytochrome P-450 enzymes in liver to form epoxy ring from double bond in bis-furan. It is reported that mutagenicity of $\mathrm{AFB}_{2}$ is 500 times less than $\mathrm{AFB}_{1}$. This is due to the luck of the double bond in bis-furan. Grate detoxification was expected because the compound lost the double bond in bis-furan ring, and changed to water-soluble compound, hardly transmit bio-membrane.

\section{Patulin}

Analytical method Patulin is toxic to many kinds of animals, such as mouse, rat, hamster, dog and chicken. Patulin contamination in apple or apple-based products has been reported worldwide. On the other hand, in Japan the situation of patulin contamination was unknown until 1995 . Only one paper reported that no patulin was found in apple juice in 1980s. In the report, number of the samples examined was less than 10 , and the detection limit was $100 \mu \mathrm{g} / \mathrm{kg}$. Since then no occurrence data was available. It seemed necessary to have data on patulin contamination in Japan. At the first step, we developed the analytical method for patulin. The limit for quantification and confirmation should be $5 \mu \mathrm{g} / \mathrm{kg}$ because the most common maximum limit for patulin in the world is $50 \mu \mathrm{g} / \mathrm{kg}$.

A sensitive and selective method for quantification and confirmation of patulin in apple juice by GC-MS was developed ${ }^{11)}$. By this method, patulin was precisely determined and confirmed down to the level of 1 and $5 \mu \mathrm{g} / \mathrm{kg}$ in sample, respectively. The selectivity, trueness, repeatability of this method is conformed to the Japanese method validation guideline. Patulin was extracted with ethyl acetate from a sample and then hexane was

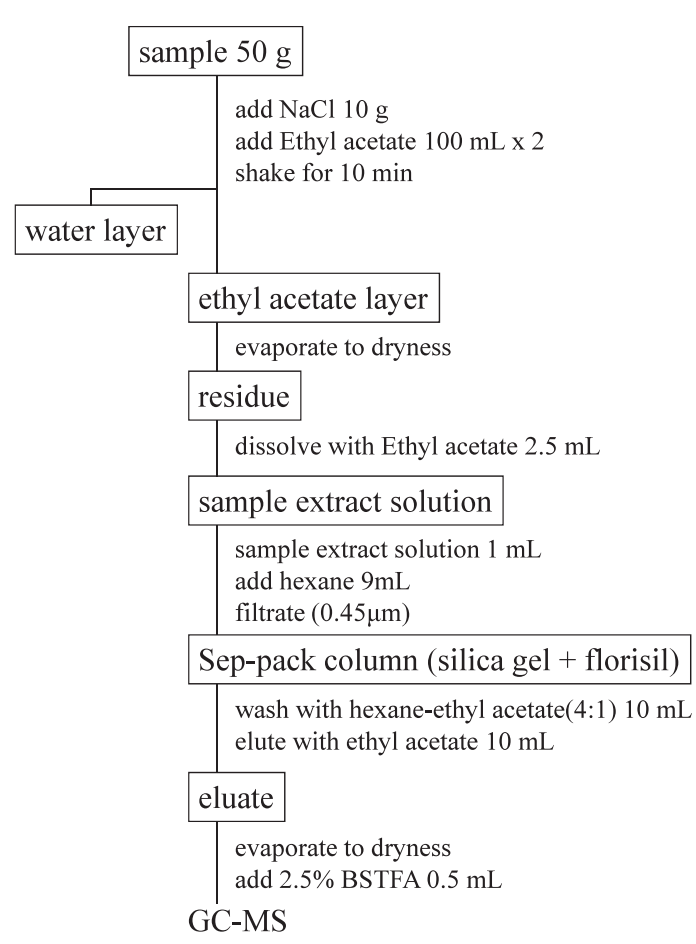

Scheme 2. Analytical method for patulin 
added to the concentrated extract solution. Significant amounts of insoluble impurities were filtered off, followed by further clean-up by the solid phase extraction with combined silica gel and florisil cartridges. The filtration step in the low-polar condition was very effective to remove the impurities in the sample extract solution. The eluate from the cartridges was evaporated to dryness under reduced pressure and patulin was determined and confirmed by GC-MS after derivatization with $2.5 \% \mathrm{~N}$, O-Bis (trimethylsilyl) trifluoroacetamide ethyl acetate solution. Patulin was determined in the selected ion monitoring mode $(\mathrm{m} / \mathrm{z} 226)$ and confirmed in the SCAN mode ( $\mathrm{m} / \mathrm{z}$ 40-340). The recovery from apple juice spiked with 10-500 $\mu \mathrm{g} / \mathrm{kg}$ ranged from 93.4 to $100 \%$. The limits of detection and quantification were $0.1(\mathrm{~S} / \mathrm{N}=3)$ and $1 \mu \mathrm{g} / \mathrm{kg}(\mathrm{S} / \mathrm{N}=30)$ of patulin in sample, respectively. Levels down to $5 \mu \mathrm{g} / \mathrm{kg}$ of patulin in sample were readily confirmed.

Contamination With the method, we started the examination of patulin contamination in apple-based products in 1996. In 1996, high level of patulin was found in apple juice concentrate. In 1998, patulin was found in commercially available apple juice. These data were first report on patulin contamination in Japan.

More than 200 samples of apple-based products, collected from market or juice plants in Japan during the years 1996 to 2001 , were examined for patulin ${ }^{12)}$. Patulin was detected in $16 \%$ of commercial apple drinks in the range of 5 to $42 \mu \mathrm{g} / \mathrm{kg}$. No commercially available apple drink contained more than $50 \mu \mathrm{g} / \mathrm{kg}$ of patulin, the regulatory limit in Japan at present. $81 \%$ of apple juice concentrates contained patulin ranged from 5 to $670 \mu \mathrm{g} / \mathrm{kg}$. We continued the examination of patulin, and found apple juice contained $92 \mu \mathrm{g} / \mathrm{kg}$ of patulin in 2002.

In 2003 , regulation on patulin in apple juice, with the maximum level of $50 \mu \mathrm{g} / \mathrm{kg}$, was enforced in Japan. After then patulin contamination in apple juice was reduced in level and incidence.

Injured apples were collected from domestic apple juice factory, and examined patulin. $10 \%$ of the apples examined were contained high level of patulin, the highest level was $10,000 \mu \mathrm{g} / \mathrm{kg}$. This result revealed that patulin contamination naturally occurs in Japan.

Risk evaluation The risk of patulin in Japan was estimated. The daily intake of patulin for mean of all population in Japan is quite below the provisional maximum tolerable daily intake (PMTDI) indicated by JECFA, $0.4 \mu \mathrm{g} / \mathrm{kg}$ body weight/day. The risk of patulin in Japan considered being negligible because the contamination level was not so high. However, apple juice can occasionally be heavily contaminated with patulin. Therefore continuing efforts are needed to minimize exposure to patulin.

\section{Ochratoxins and citrinin}

Analytical method Methods using HPLC-FL and using liquid chromatography with tandem mass spectrometry (LC-MS/MS) were developed for simultaneous determination of ochratoxin A (OTA), ochratoxin B (OTB) and citrinin (CIT) in cereal, fruit, and coffee products ${ }^{13)}$. The samples were extracted with ethyl acetate under an acidic condition, and then cleaned up with liquid-liquid separation. The test solution was analyzed by reverse-phase HPLC-FL and liquid chromatography coupled with tandem mass spectrometry (LC-MS/MS). Mass spectral acquisition was performed in positive ion mode by applying multiple reaction monitoring. The performances of both detectors were almost equivalent. The recoveries of OTA and OTB were $87 \sim 111 \%$, and that of CIT were $70 \sim 88 \%$. The limits of quantification ( $\mathrm{S} / \mathrm{N}=10$ ) of OTA, OTB and 
CIT was $0.1 \mu \mathrm{g} / \mathrm{kg}$ or less. These methods were considered to be useful for the quantification of the three mycotoxins at low levels $(0.1 \mu \mathrm{g} / \mathrm{kg})$.

Contamination OTA, OTB and CIT in commercial foods were simultaneously determined with HPLC-FL and confirmed with TLC, methylation or LC-MS/MS.

Until 2004 , TLC or methylation was used for confirmation of ochratoxins and citrinin. Limits of quantification for 3 toxins by HPLC were $0.1 \mu \mathrm{g} / \mathrm{kg}$, but limit of confirmation was $1 \mu \mathrm{g} / \mathrm{kg}$. Therefore, the levels of positive samples were not less than $1 \mu \mathrm{g} / \mathrm{kg}$. The analytical result during the period of 1982 to 1993 was shown on Table 4 and 5. In 3,092 samples examined, OTA was detected found in 34 samples, and CIT was detected in 71 samples. The incidence of OTA in this period was $1 \%$. The highest level of OTA and OTB was found in beans for bean-jam, the levels were $25 \mu \mathrm{g} / \mathrm{kg}$ and $3.6 \mu \mathrm{g} /$

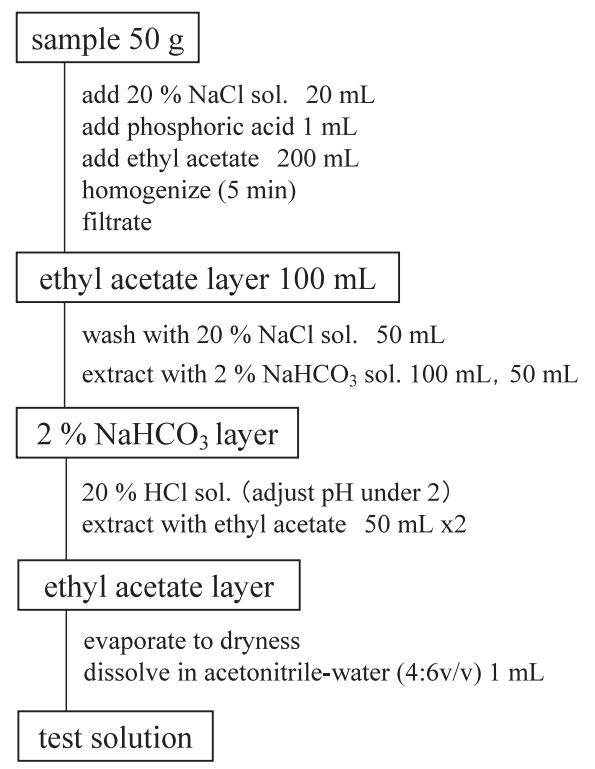

Scheme 3. Analytical method for OTA, OTB and CIT $\mathrm{kg}$, respectively. The highest level of CIT was found in ciox seed, with the level of $160 \mu \mathrm{g} / \mathrm{kg}$. Co-contamination of OTA and CIT was found in rye, coix seed, and buckwheat $^{14)}$.

The analytical result during the period of 1997 to 2004 was shown on Table 6. In this period, limit of confirmation was also $1 \mu \mathrm{g} / \mathrm{kg}$. OTA was found in wheat, rye, buckwheat, and coffee. Among them, high level of OTA, OTB and CIT was found in rye, the levels were $28,9.0$, and $26 \mu \mathrm{g} / \mathrm{kg}$, respectively.

In 2005, confirmation method with LC-MS/MS was established. After then limits of confirmation for OTA, OTB and CIT were $0.1 \mu \mathrm{g} / \mathrm{kg}$. OTA, OTB and CIT in commercial foods were simultaneously determined and confirmed with HPLC and LC-MS/MS. The samples examined were made up of cereal, fruit, coffee, and cacao products. Aflatoxins, deoxynivalenol (DON) and fumonisins were also surveyed. Of 157 samples examined, 44 were contaminated with OTA at levels of 0.11 to $4.0 \mu \mathrm{g} / \mathrm{kg}^{15)}$. At least 2 positive samples were labeled as domestics. In most positive samples, the OTA level was low, less than $1 \mu \mathrm{g} / \mathrm{kg}$. The

Table 4. Contamination level of ochratoxins and citrinin (1982 to 1993)

\begin{tabular}{lccc}
\hline \multirow{2}{*}{ Sample } & \multicolumn{3}{c}{ Level $(\mu \mathrm{g} / \mathrm{kg})$} \\
\cline { 2 - 4 } & OTA & OTB & CIT \\
\hline Barley & 4.5 & $<1$ & $<1$ \\
Rye & 3.6 & $<1$ & 2.4 \\
Coix seed & $1.1-1.2$ & $<1$ & $1.9-160$ \\
Mixed flour & 1.6 & $<1$ & $<1$ \\
Buckwheat & $1.0-3.2$ & $<1$ & $<1$ \\
Coffee & 2.8 & $<1$ & $<1$ \\
Bean for bean paste & $1.4-25$ & $1.3 \sim 3.6$ & \\
\hline
\end{tabular}

No. of tested samples; 3092 
Table 5. Co-occurrence of ochratoxin and citrinin (1982 to 1993)

\begin{tabular}{lccc}
\hline & \multicolumn{3}{c}{ No. of positive samples } \\
\cline { 2 - 4 } & OTA only & OTA and CIT & CIT only \\
\hline Barley & 1 & 0 & 0 \\
Rye & 0 & 1 & 0 \\
Coix seed & 2 & 1 & 46 \\
Mixed flour & 1 & 0 & 0 \\
Buckwheat & 4 & 13 & 0 \\
Coffee & 2 & 0 & 0 \\
Bean for bean paste & 9 & 0 & 0 \\
\hline
\end{tabular}

Table 6 Contamination of ochratoxins and citrinin (1997-2004)

\begin{tabular}{|c|c|c|c|c|c|c|}
\hline \multirow{2}{*}{ sample } & \multicolumn{2}{|c|}{ OTA } & \multicolumn{2}{|c|}{ OTВ } & \multicolumn{2}{|c|}{ CIT } \\
\hline & incidence & range $* 1$ & incidence & range & incidence & range \\
\hline wheat & $2 / 57$ & $1.1,2.0$ & $0 / 57$ & $<1$ & $0 / 57$ & $<1$ \\
\hline barley & $0 / 112$ & $<1$ & $0 / 112$ & $<1$ & $0 / 112$ & $<1$ \\
\hline oat & $0 / 11$ & $<1$ & $0 / 11$ & $<1$ & $0 / 11$ & $<1$ \\
\hline rye & $1 / 1$ & 28 & $1 / 1$ & 9 & $1 / 1$ & 26 \\
\hline coix seed & $0 / 12$ & $<1$ & $0 / 12$ & $<1$ & $5 / 12$ & $4.6 \sim 12$ \\
\hline buckwheat & $3 / 54$ & $1.3 \sim 2.4$ & $0 / 54$ & $<1$ & $0 / 54$ & $<1$ \\
\hline rice & $0 / 16$ & $<1$ & $0 / 16$ & $<1$ & $0 / 16$ & $<1$ \\
\hline corn & $0 / 45$ & $<1$ & $0 / 45$ & $<1$ & $0 / 45$ & $<1$ \\
\hline coffee & $1 / 19$ & 4.8 & $0 / 19$ & $<1$ & $0 / 5$ & $<1$ \\
\hline bean for bean paste & $0 / 47$ & $<1$ & $0 / 47$ & $<1$ & $0 / 47$ & $<1$ \\
\hline dry fruit & $0 / 4$ & $<1$ & $0 / 4$ & $<1$ & $0 / 4$ & $<1$ \\
\hline others & $0 / 8$ & $<1$ & $0 / 8$ & $<1$ & $0 / 8$ & $<1$ \\
\hline Total & $7 / 386$ & & $1 / 386$ & & $6 / 372$ & \\
\hline
\end{tabular}

* $1: \mu \mathrm{g} / \mathrm{kg}$

Table 7. Ochratoxins and other mycotoxins in cereal products (2005)*

\begin{tabular}{|c|c|c|c|c|c|c|c|c|c|c|c|c|}
\hline \multirow{3}{*}{ Sample } & \multirow{3}{*}{$\begin{array}{l}\text { No. of } \\
\text { sample }\end{array}$} & \multicolumn{3}{|c|}{ Ochratoxins } & \multicolumn{2}{|c|}{ CIT } & \multicolumn{2}{|c|}{$\mathrm{AF}$} & \multicolumn{2}{|c|}{ DON } & \multicolumn{2}{|r|}{ FM } \\
\hline & & \multirow{2}{*}{$\begin{array}{l}\text { No. of } \\
\text { positive }\end{array}$} & \multicolumn{2}{|c|}{ Range ( $\mu \mathrm{g} / \mathrm{kg}$ ) } & \multirow{2}{*}{$\begin{array}{c}\text { No. of } \\
\text { positive }\end{array}$} & \multirow{2}{*}{$\begin{array}{l}\text { Range } \\
(\mu \mathrm{g} / \mathrm{kg})\end{array}$} & \multirow{2}{*}{$\begin{array}{c}\text { No. of } \\
\text { positive }\end{array}$} & \multirow{2}{*}{$\begin{array}{l}\text { Range } \\
(\mu \mathrm{g} / \mathrm{kg})\end{array}$} & \multirow{2}{*}{$\begin{array}{c}\text { No. of } \\
\text { positive }\end{array}$} & \multirow{2}{*}{$\begin{array}{l}\text { Range } \\
\text { (mg/kg) }\end{array}$} & \multirow{2}{*}{$\begin{array}{c}\text { No. of } \\
\text { positive }\end{array}$} & \multirow{2}{*}{$\begin{array}{l}\text { Range } \\
(\mathrm{mg} / \mathrm{kg})\end{array}$} \\
\hline & & & OTA & отв & & & & & & & & \\
\hline Wheat & 12 & 6 & $0.12-0.30$ & $<0.1$ & 1 & 0.19 & 0 & $<0.1$ & 3 & $0.15-1.1$ & - & \\
\hline Barley & 3 & 0 & $<0.1$ & $<0.1$ & 0 & $<0.1$ & 0 & $<0.1$ & 0 & $<0.1$ & - & \\
\hline Oat & 3 & 0 & $<0.1$ & $<0.1$ & 0 & $<0.1$ & 0 & $<0.1$ & 0 & $<0.1$ & - & \\
\hline Rye & 1 & 0 & $<0.1$ & $<0.1$ & 0 & $<0.1$ & 0 & $<0.1$ & 0 & $<0.1$ & - & \\
\hline & & & & & 0 & & 1 & $\mathrm{~B}_{1}: 1.1, \mathrm{~B}_{2}: 0.1$ & - & & - & \\
\hline Coix seed & 2 & 0 & $<0.1$ & $<0.1$ & 0 & $<0.1$ & 0 & $<0.1$ & - & & - & \\
\hline Rice & 5 & 0 & $<0.1$ & $<0.1$ & 0 & $<0.1$ & 0 & $<0.1$ & & & - & \\
\hline Buckwheat & 2 & 2 & $0.12,0.45$ & $<0.1$ & 2 & $0.55,0.62$ & 0 & $\begin{array}{l}<0.1 \\
<0.1\end{array}$ & - & & - & \\
\hline Corn & 3 & 0 & $<0.1$ & $<0.1$ & 0 & $<0.1$ & 0 & $<0.1$ & - & & 2 & $\mathrm{~B}_{1}: 0.05,0.04, \mathrm{~B}_{2}: 0.01$ \\
\hline Others & 6 & 0 & $<0.1$ & $<0.1$ & 0 & $<0.1$ & 0 & $<0.1$ & 1 & 0.17 & - & - \\
\hline
\end{tabular}


Table 8. Ochratoxins and other mycotoxins in fruit, coffee and cacao products*

\begin{tabular}{|c|c|c|c|c|c|c|c|c|}
\hline \multirow{3}{*}{ Sample } & \multirow{3}{*}{$\begin{array}{l}\text { No. of } \\
\text { sample }\end{array}$} & \multicolumn{3}{|c|}{ Ochratoxins } & \multicolumn{2}{|c|}{ CIT } & \multicolumn{2}{|r|}{$\mathrm{AF}$} \\
\hline & & \multirow{2}{*}{$\begin{array}{c}\text { No. of } \\
\text { positive }\end{array}$} & \multicolumn{2}{|c|}{ Range ( $\mu \mathrm{g} / \mathrm{kg}$ ) } & \multirow{2}{*}{$\begin{array}{c}\text { No. of } \\
\text { positive }\end{array}$} & \multirow{2}{*}{$\begin{array}{l}\text { Range } \\
(\mu g / k g)\end{array}$} & \multirow{2}{*}{$\begin{array}{c}\text { No. of } \\
\text { positive }\end{array}$} & \multirow{2}{*}{ Range $(\mu \mathrm{g} / \mathrm{kg})$} \\
\hline & & & OTA & OTB & & & & \\
\hline
\end{tabular}

\begin{tabular}{|c|c|c|c|c|c|c|c|c|}
\hline \multicolumn{9}{|l|}{ Fruit products } \\
\hline \multicolumn{9}{|l|}{ Grape products } \\
\hline Raisin & 13 & 6 & $0.14-0.70$ & $<0.1$ & 0 & $<0.1$ & - & \\
\hline Juice & 11 & 1 & 0.11 & $<0.1$ & 0 & $<0.1$ & - & \\
\hline Wine & 14 & 1 & 0.15 & $<0.1$ & 0 & $<0.1$ & - & \\
\hline Vinegar & 6 & 1 & 0.80 & 0.29 & 0 & $<0.1$ & - & \\
\hline Others ${ }^{* 1}$ & 3 & 1 & 4.0 & 1.8 & 0 & $<0.1$ & - & \\
\hline \multicolumn{9}{|l|}{ Cassis products } \\
\hline Dry cassis & 1 & 1 & 0.38 & $<0.1$ & 0 & $<0.1$ & - & \\
\hline Liquor & 6 & 0 & $<0.1$ & $<0.1$ & 0 & $<0.1$ & - & \\
\hline Other $^{* 2}$ & 1 & 0 & $<0.1$ & $<0.1$ & 0 & $<0.1$ & - & \\
\hline \multicolumn{9}{|l|}{ Cacao products } \\
\hline Cacao powder & 12 & 10 & $0.25-0.67$ & $0.10-0.17$ & - & & 5 & $\mathrm{~B}_{1} ; 0.2-0.6, \mathrm{~B}_{2} ; 0.1, \mathrm{G}_{1} ; 0.2$ \\
\hline Сocoa & 8 & 5 & $0.11-0.35$ & 0.10 & - & & 0 & $<0.1$ \\
\hline \multicolumn{9}{|l|}{ Coffee products } \\
\hline Raw coffee & 10 & 2 & $0.51,0.81$ & 0.10 & 0 & $<0.1$ & - & \\
\hline Roasted coffee & 23 & 3 & $0.25-0.43$ & - & - & & - & \\
\hline Instant coffee & 7 & 5 & $0.16-1.1$ & - & - & & - & \\
\hline Coffee drink & 5 & 0 & $<0.1$ & - & - & & - & \\
\hline
\end{tabular}

$* 1$ : grape soaked in syrup, puree and liquor, $* 2$ : mixed fruit product $\quad-$ : not tested

* Tabata, S., et.al.,. Shokuhin Eiseigaku Zasshi (Food Hyg. Saf. Sci.), 49, 111-115 (2008)

Table 9. Co-occurrence of mycotoxins*

\begin{tabular}{|c|c|c|c|c|c|c|}
\hline Sample & $\begin{array}{l}\text { No. of } \\
\text { sample }\end{array}$ & $\begin{array}{c}\text { OTA } \\
(\mu \mathrm{g} / \mathrm{kg})\end{array}$ & $\begin{array}{c}\text { ОТВ } \\
(\mu \mathrm{g} / \mathrm{kg})\end{array}$ & $\begin{array}{c}\text { CIT } \\
(\mu \mathrm{g} / \mathrm{kg})\end{array}$ & $\begin{array}{c}\mathrm{AFB}_{1} \\
(\mu \mathrm{g} / \mathrm{kg})\end{array}$ & $\begin{array}{c}\mathrm{DON} \\
(\mathrm{mg} / \mathrm{kg})\end{array}$ \\
\hline \multirow[t]{2}{*}{ Wheat flour } & 12 & 0.30 & $<0.1$ & 0.19 & $<0.1$ & 0.15 \\
\hline & & 0.15 & $<0.1$ & $<0.1$ & $<0.1$ & 0.25 \\
\hline \multirow[t]{2}{*}{ Buckwheat flour } & 2 & 0.45 & $<0.1$ & 0.55 & $<0.1$ & 一 \\
\hline & & 0.12 & $<0.1$ & 0.62 & $<0.1$ & - \\
\hline \multirow[t]{5}{*}{ Cacao powder } & 12 & 0.67 & $<0.1$ & - & 0.2 & - \\
\hline & & 0.56 & $<0.1$ & - & 0.2 & - \\
\hline & & 0.52 & 0.17 & - & 0.6 & - \\
\hline & & 0.34 & 0.10 & - & 0.4 & - \\
\hline & & 0.28 & $<0.1$ & - & 0.3 & - \\
\hline
\end{tabular}

highest incidence of OTA was observed in cacao powder (10/12), followed by instant coffee (5/7), cocoa (5/8) and raisin (6/13). OTB was found in fruit and cacao products containing relatively high levels of OTA.

Co-occurrence of OTA, CIT and DON was found in cereal products, and co-occurrence of OTA and 
Table 10. Extraction of OTA in roasted coffee bean by paper drip*

\begin{tabular}{lcccc}
\hline Sample & $\begin{array}{c}\text { Concentration } \\
\text { in bean }(\mu \mathrm{g} / \mathrm{kg}) \\
(\text { mean } \pm \mathrm{SD})\end{array}$ & $\begin{array}{c}\text { Amount in } \\
\text { bean }(\mathrm{ng} / 25 \mathrm{~g}) \\
(\text { mean } \pm \mathrm{SD})\end{array}$ & $\begin{array}{c}\text { Amount } \\
\text { in extract }(\mathrm{ng}) \\
(\text { mean } \pm \mathrm{SD})\end{array}$ & $\begin{array}{c}\mathrm{n}=3 \\
\text { of Extraction }(\%) \\
\text { (mean) }\end{array}$ \\
\hline No. 1 & $0.43 \pm 0.05$ & $10.75 \pm 1.15$ & $3.44 \pm 0.93$ & 32.0 \\
No. 2 & $0.28 \pm 0.05$ & $6.92 \pm 1.26$ & $2.55 \pm 0.71$ & 36.8 \\
\hline
\end{tabular}

* Tabata, S., et. al.,. Shokuhin Eiseigaku Zasshi (Food Hyg. Saf. Sci.), 49, 111-115 (2008)

aflatoxin was found in cacao products.

With roasted coffee naturally contaminated with OTA, transfer rate of OTA from the coffee bean to the extract was investigated. Twenty five gram of roasted and ground coffee bean were extracted with $375 \mathrm{~mL}$ of boiling water. As a result, approximately $30 \%$ of naturally contaminated OTA in roasted coffee bean moved into the extract when brewed with paper filter.

\section{Fumonisins}

Contamination Fumonisin $\mathrm{B}_{1}$ and $\mathrm{B}_{2}$ were examined in the period of 2003 to 2007 . The samples were corn-based products collected from markets in Tokyo. They were analyzed by AOAC Official Methods of Analysis 995.15 . The limit of quantification is $0.01 \mathrm{mg} / \mathrm{kg}$. All samples detected fumonisin by HPLC were confirmed by LC-MS/MS. The results were presented on Table 11. Fumonisins were found in corn grit, corn flour and pop corn in high incidence, 59-100\%. One sample contained high level of fumonisins, $1.7 \mathrm{mg} / \mathrm{kg}$ of fumonisin $B_{1}$ and $0.45 \mathrm{mg} / \mathrm{kg}$ of fumonisin $\mathrm{B}_{2}$. Those levels were exceeded the regulation level in European Union, although no regulation is set on fumonisins in Japan.

Analytical method $\quad$ For analysis of fumonisin $\mathrm{B}_{1}$ and $\mathrm{B}_{2}$, AOAC Official Methods of Analysis 995.15 is commonly used worldwide. The recovery of the method is good for corn grit or corn flour, but not good for corn snacks. An analytical method for fumonisins in corn snack was developed. The condition of the purification with solid phase extraction, and extracting solvent were examined. As the result, the suitable conditions were found and a new method for fumonisin $\mathrm{B}_{1}, \mathrm{~B}_{2}$ and $\mathrm{B}_{3}$ in corn snack was established.

Table 11. Fumonisin contamination (2003-2007)

\begin{tabular}{lcccc}
\hline \multirow{2}{*}{ sample } & No. of sample & No. of positive & \multicolumn{2}{c}{ level (mg/kg) } \\
\cline { 4 - 5 } & & & FMB $_{1}$ & FMB $_{2}$ \\
\hline Corn grit & 14 & 13 & $0.02-0.18$ & $0.01-0.05$ \\
Corn flour & 8 & 8 & $0.04-1.7$ & $0.03-0.45$ \\
Popcorn & 27 & 16 & $0.01-0.55$ & $0.01-0.03$ \\
Sweet corn & 4 & 0 & $\mathrm{ND}$ & $\mathrm{ND}$ \\
Corn cereal & 6 & 1 & 0.02 & $\mathrm{ND}$ \\
Corn snack & 5 & 1 & 0.01 & $\mathrm{ND}$ \\
Corn starch & 1 & 0 & $\mathrm{ND}$ & $\mathrm{ND}$ \\
Giant corn & 3 & 0 & $\mathrm{ND}$ & $\mathrm{ND}$ \\
\hline Total & 68 & 39 & & $\mathrm{ND}:<0.01 \mathrm{mg} / \mathrm{kg}$
\end{tabular}




\section{Deoxynivalenol}

Table 12 shows the contamination of deoxynivalenol (DON) examined in the period of 2003 to 2007 . The samples were cereals collected from market in Tokyo. They were analyzed by the official method for DON in Japan. The limit of quantification is $0.1 \mathrm{mg} / \mathrm{kg}$. All samples detected DON by HPLC was confirmed by LC-MS/MS. DON was found in wheat samples at the level of $0.1-1.1 \mathrm{mg} / \mathrm{kg}$. The highest level, $1.1 \mathrm{mg} / \mathrm{kg}$, was same level as the regulation limit. If someone intake $45.5 \mathrm{~g}$ of this sample every day, the intake of DON is same level as PMTDI.

\section{Conclusion}

Aflatoxins were found in several kinds of foods and foodstuffs every year, and some of them contain more than $10 \mu \mathrm{g} / \mathrm{kg}$ of aflatoxin, the regulatory limit in Japan. Most of aflatoxins in foods remain after cooking, and detoxification of aflatoxins in foods were found out to be difficult. Therefore, to protect consumer from the harmful effects of aflatoxin, careful examination for aflatoxin considered being important.

Patulin contamination in apple juice was found at the first time in Japan, but the contamination was reduced after publication of the contamination data and establishment of the regulation.

Low level but high incidence of OTA was found in cereals, coffee, cacao and dried fruit, and some cereal samples were co-contaminated with citrinin.

Change in the incidence and level of mycotoxins suggested that regulation for mycotoxins and publication of the contamination data are effective to reduce mycotoxin contamination in commercially available foods in Japan. For food safety, it was expected to set regulation on OTA, zearalenone, fumonisins in near future.

I am deeply grateful to Dr. Nishijima, Dr. Ibe, Dr. Kamimura, Dr. Morozumi, Dr. Nakazato, Dr. Saito and co-workers of Tokyo Metropolitan Institute of Public Health for their support and encouragement. Special thanks were extended to Dr. Ichinoe of Tokyo Kasei University and Dr. Takahashi of Public Health

Table 12. Deoxynivalenol contamination (2003-2007)

\begin{tabular}{lccc}
\hline sample & No. of sample & No. of positive & level $(\mathrm{mg} / \mathrm{kg})$ \\
\hline Wheat & & 3 & \\
Wheat flour & 15 & 0 & $0.1-0.25$ \\
pasta & 10 & 2 & ND \\
others & 3 & 0 & $0.17,1.1$ \\
Barley & 3 & 0 & ND \\
Oat & 4 & 0 & ND \\
Ciox seed & 2 & 0 & ND \\
Rye & 1 & 0 & ND \\
Mixture & 6 & 0 & ND \\
Rice & 34 & 5 & ND \\
\hline Total & 78 & \multicolumn{2}{c}{ ND: $<0.1 \mathrm{mg} / \mathrm{kg}$}
\end{tabular}


Laboratory of Chiba Prefecture. They expanded my knowledge of mycotoxin-producing fungi, and taught me about the importance of the investigation in the field of mycotoxin contamination. Finally, I would like to express thanks to all collaborators in my research for their help and support.

\section{References}

1 ) Kamimura, H., Nishijima, M., Yasuda, K., Ushiyama, H., Tabata, S., Matsumoto, S., Nishima, T.: J. of A.O.A.C, 68, 458-461 (1985)

2 ) Tabata, S., Kamimura, H., Tamura, Y., Ysuda, K., Ushiyama, H., Hashimoto, H. Nishijima, M., and Nishima, T.: Shokuhin Eiseigaku Zasshi (Food Hyg. Saf. Sci.), 28, 395-401 (1987)

3 ) Tabata, S., Kamimura, H., Ibe, A., Hashimoto, H., Iida, M., Tamura, Y., and Nishima, T.: J. of AOAC International, 76, 32-35 (1993)

4 ) Tabata, S., Ibe, A., Ozawa, H., Kamimura, H., Yasuda, K.: J. of Food Hyg. Soc. Japan, 39, 444-447 (1998)

5 ) Tabata, S.: Mycotoxins, 47, 9-14 (1998)

6 ) Tabata, S., Kamimura, H., Tamura, Y., Ibe, A., Hashimoto, H. and Nishima, T.: Shokuhin Eiseigaku Zasshi (Food Hyg. Saf. Sci.), 33, 150-156 (1992)

7 ) Tabata, S., Kamimura, H., Ibe, A., Aoyama, T., Tamura, Y.: Jpn. Food Microbiol., 12, 243-248 (1996)

8 ) Kimura, N.: Japanese Patent Journal (1988)

9 ) Tabata, S., Kamimura, H., Ibe, A., Hashimoto, H., Tamura, Y: J. of food protection, 57, $42-47$ (1994)

10) Tabata, S., Kamimura, H., Nishijima, M., Tanabe, S.: J. of Food Hyg. Soc. Japan, 40, 431-437 (1999)

11) Tabata, S., Iida, K., Suzuki, J., Kimura, K., Ibe, A., Saito, K.: Shokuhin Eiseigaku Zasshi (Food Hyg. Saf. Sci.) 45, 245-249 (2004).

12) Tabata, S.: Mycotoxins, 58. 129-135 (2008)

13) Tabata, S., Iida, K., Kimura, K., Iwasaki, Y., Nakazato, M., Kamata, K., Hirokado, M.: Shokuhin Eiseigaku Zasshi (Food Hyg. Saf. Sci.), 49, 100-105 (2008)

14) Tabata, S., Nakazato, M.: Mycotoxins, 57, 37-46 (2007)

15) Tabata, S., Iida, K., Kimura, K., Iwasaki, Y., Nakazato, M., Kamata, K., Hirokado, M.: Shokuhin Eiseigaku Zasshi (Food Hyg. Saf. Sci.), 49, 111-115 (2008) 